\title{
Influence of Governing Mechanism on Financial Performance: A Study on Royal Bank of Bhutan and Bank of Ceylon
}

\author{
UPANANDA, W. A. ${ }^{1}$, KUMARA, U. E. S. ${ }^{2}$ \\ ${ }^{1}$ Department of Banking and Finance, Faculty of Business Studies, \\ Wayamba University of Sri Lanka, Kuliyapitiya, \\ SRI LANKA \\ ${ }^{2}$ Department of Accounting and Finance, Faculty of Business Studies, \\ Wayamba University of Sri Lanka, Kuliyapitiya \\ SRI LANKA
}

\begin{abstract}
:-
Generally ownership of banks in developing countries is dominated by the state of respective countries. Some researchers claim that that nearly 42 percent of the equity of top ten banks belonged to the state while few researchers contend that such government ownership of banks is detrimental to the growth. However, some studies show that developing countries continued to maintain high share of equities in top banks. However, the gravity of criticism against these banks, according to some empirical studies, had been lessened by the high profit abilities of these banks. Since there are majority of countries governed by democratically elected governments few governed by monarchical rule of governments, this study attempt to explore the structure of financial performance of state owned banks in respective governing mechanisms raising the research question, ' does form of governing mechanism influence the structure of financial performance of state owned banks'. To address this question, this study selects two leading state owned banks in respective countries; Sri Lanka (democratic form of government) and Bhutan (monarchical form of government) to examine financial performance of banks using CAMEL framework for five years (2009 to 2013 ). Analysis of financial performance which was extracted from Annual Reports of last five years shows that there is no significant difference between capital adequacy ratios. But profitability ratios of Bank of Bhutan are much higher than that of Bank of Ceylon. Although liquidity and asset quality were not compared due to nonavailability of data in Bank of Bhutan Annual Reports, management quality is much higher in state bank in Bhutan. Although Bank of Bhutan has comparatively shorter years of experience (47 years), the Bank has utilized financial resources more efficiently than Bank of Ceylon which has comparatively longer history (75 years). Therefore this study concludes that intervention of democratically elected government in Sri Lanka may have greater influence on fund utilization/investment decisions.
\end{abstract}

Keywords: -State-owned banks, Financial Performance, Monarchical, Democratic 


\section{Introduction}

Generally ownership of banks in developing countries is dominated by the state. La Porte et. al. (2002) contends that 42 percent of the equity of top ten banks belonged to respective governments. Some researchers state that such government ownership of banks has been empirically found to be detrimental to growth (Shleifer and Vishny, (1994); La Porta et al., (2002). Irrespective of these findings, majority of governments, according to above authors continued to maintain high share of equities in top banks. Moreover, these state owned banks claim high financial performance and larger market share which could nullify criticism against negative impact on the growth. State in this paper refers to the governing authority which may be democratically elected or continued to be monarchical. Then the purpose of this study is to explore whether there is a variation of financial performance with respect to the governing mechanism with regard to the research question 'does the form of governing mechanism influence the financial performance of state owned banks'. To address this question, this study selects two leading state owned banks in respective countries; Sri Lanka (democratic form of government) and Bhutan (monarchical form of government). Next this study examines the financial performance of bank using CAMEL framework for five years to compare each component in the CAMEL framework. Analysis of financial performance extracted from Annual Reports of last five years (2009 to 2012) shows that there is no difference between ratios of financial performance but there is difference in financial resource utilization efficiency. Although Bank of Bhutan has comparatively shorter years of experience it has utilized financial resources more efficiently than that Bank of Ceylon which celebrated its 75th year of existence recently.

\section{1 Problem Background}

Bank of Ceylon celebrates its 75th year in operation in August 2014. Started in August 1st in 1939 as a private bank under colonial era Bank of Ceylon (BoC) was nationalized in 1961 (BoC Annual Reports; Central Bank Annual Reports). The institutional context of the Bank could be divided into four sectors under four governance mechanisms: 1939 to 1947 (Colonial); 1948 to 1960 (liberalized economic policy regime); 1961 to 1977 (closed market policy regime); 1978 to 2014 (liberalized policy regime). Although growth of $\mathrm{BoC}$ is continued, variation of relative financial performance varies between these governing mechanisms. Currently $\mathrm{BoC}$ hold 55 percent of trade finance market. In contrast, Bank of Bhutan (BoB) was incorporated in 1968 as a public commercial bank and collaborated with State Bank of India (SBI) in 1972) on capital sharing basis $(60: 40$ which reduced to 20 percent in 1987) (Annual Reports of Bank of Bhutan). Under this agreement, SBI was responsible for management and continued this policy until 1997. The management of BoB was transferred Druk Holding Investing (DHI) Company Limited in 2007 (BoB Annual Report 2009). During this transformation, the country continued be under monarchial rule (since 1903).

As preceding sections explained, financial performance of bank continued to grow in two contrasting governing mechanisms. While Bank of Ceylon is operating under parliamentary system, Bank of Bhutan is under monarchial rule of government. Generally, political influence on state-run corporations is becoming greater (Kelegama, 2003). As a result it may be argued that major investment and managerial decisions are made with the consultation of the state. These decisions may not be the optimum 
decisions for financial performance of the banks. Then it is reasonable to argue that governing mechanisms could be responsible for financial performance of state-owned banks.

\subsection{Significance of the Study}

Generally, state owned banks are growing in economies with the patronage of respective governments and claim high financial performance which may camouflage fund allocation and utilization inefficiencies. Even though this situation arises as a result of intervention of respective government (i.e., state banks hold majority of state accounts), state-owned banks claim higher growth in terms of market share and profits, and attribute these success to entrepreneurial activities and efficient managerial policies and practices of the Bank. Studies which examine these claims rationally are rare in Sri Lanka and even rarer in Bhutan. Examining whether the growth is actually taken place due to entrepreneurial activities/management efficacies may help banks to review their policies and practices for more prudent policies.

\section{Literature Review}

Models which explained financial intermediation was originally based on Arrow-Debreu model and later on Modigliani-Miller theorem (Modigliani and Merton, 1958). Both were developed under perfect market where financial intermediation has no role to play. Because under the assumptions of perfect market, no asymmetry of information or transaction cost exist. In other words allocation of resources is efficient and intermediaries have no role to play. In practice, however, financial markets emerged to improve the efficiency of allocation of resources and to reduce asymmetry of information. Research on influence of governing mechanism on efficiency of resource allocation and reducing asymmetry of information is rare. And this study attempt to build theory to reduce this knowledge gap.

Generally private ownership of firms is considered to promote efficiency (Shleifer and Vishny, 1994; La Porta et al., 2002). The political view explaining this variation argues that the political interference can distort the objectives and constraints faced by managers which raise the operating cost of the firm. The managerial view, on the other hand, contends that privatization improves performance because state-owned firms have difficulty monitoring managers (Laffont and Tirole, 1993) which may give rise to administration $\mathrm{n}$ cost. Moreover, there is significant amount of literature which state that state-owned firms perform poorly (Gosh, 2010). This could especially be relevant in developing economies where inadequacies in the financial system underdeveloped capital markets, weak bankruptcy procedures and the associated legal deficiencies (Caves, 1990; Adam et. al., 1992). Under these conditions Gosh (2010), who examined similarities and differences of state-owned and private commercial banks, contends that although there are similarities between state-owned banks and private banks, two main differences exists: namely nonfinancial performance and the variation of interest rates. To eliminate these differences, this study select two state owned banks in different contexts and compare structure of financial performance thereby attempts to explore under what conditions these banks claim high financial performance.

According to above reviewed literature indicates that early models of financial intermediation have failed to explain financial market development in the recent time under assumptions on perfect 
market conditions. Next the review explored that private banks perform better than state owned banks. Then it is necessary to understand how state-owned banks claim high financial performance irrespective of high operating cost and administrative costs. One plausible argument is state patronage had negate the losses incurred due to high operating cost and administrative cost. Upon this literature review following conceptual framework is drawn.

\subsection{Conceptual Framework}

\section{Fig.1: Conceptual Framework}

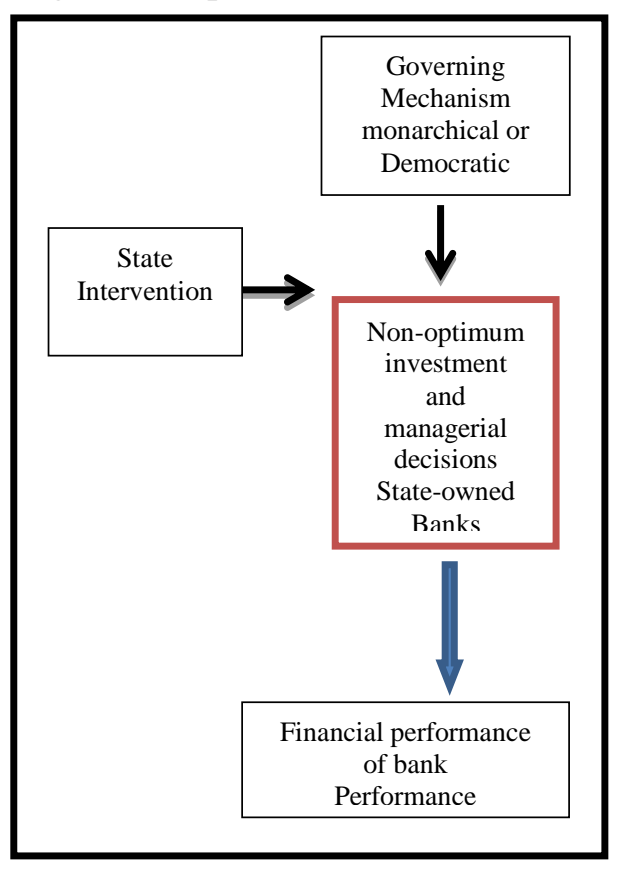

\section{$3 \quad$ Methodology}

Since controlling numerous variables associated with financial performance of banks is difficult, deductive approach which seeks representative sample may not appropriate to study a unique case. Further banks are institutions of which boundaries are difficult to separate from its context. Majority of scholars advocates employing deductive approach to explore reasons behind high financial performance of some banks (Yin, 2003). Within deductive approach, case study approach has been advocated by scholars to investigate phenomenon which is difficult to separate from its context (Yin, 2003; Eisenhardt, 1989). Hence this study adopts case study strategy to assess financial performance of stateowned banks. To eliminate endemic numerous variables in the contexts, two banks in two contexts but differs in governing mechanisms are selected (democratic form of government and monarchical form of government). Also these authors state that single case could be used when it is a unique case. Within this unique case, according to Yin (2003: 42), could have several units of analysis. Accordingly, two unique cases (Bank of Ceylon and Bank of Bhutan) in two countries (Sri Lanka and Bhutan) are selected. Each bank is unit of analysis (see Yin, 2003) embedded in each country. Governing mechanism is the higher level of unit of analysis while banks are embedded cases within the governing mechanism. As financial performance is ultimate indicator of performance this study assumes performance of respective banks is proxy to financial performance. Next section deals with measurement which ascertains the financial performance of bank. The framework mentioned below is the most widely used criteria in the world adopted under Basel recommendation of 2011 (see Basel Committee recommendation, 2011).

\subsection{Measuring Financial Performance}

CAMEL framework has been used by researcher and practitioners to measure performance of banks (Gosh, 2010; Sharma, 2010). In CAMEL, according to these authors in consistent with Basel recommendations, 201, ' $\mathrm{C}$ ' stands for capital adequacy which assess the strength of bank to absorb, reasonable 
amount of losses while 'A' stands for asset quality which measures the ratio between non-performing assets and total assets. Management efficiency (M) is assessed through five ratios: total assets to total deposits (ability of bank to convert deposit available into high earning advances; business per employee (BPE) (productivity of employees); profit per employees (PPE) which is calculated by dividing profit after tax by the number of employees. Earning quality (E) is measured by five ratios including operating profit to average working funds (OP/AWF) which ratio indicates how much a bank can earn profit from its operations for every rupee spent in the form of working fund and spread to total assets (spread is the difference between the interest earned and interest expended). Liquidity (L) in CAMEL framework measures the ability of banks hedge against liquidity risk. Liquidity is measured from five ratio including liquid assets to total assets and liquid assets to total deposits. Even though all these measures are important in measuring performance, management efficiency and the earning quality, are the two measures which may vary with the nature of governing mechanism. Then the result obtained from CAMEL analysis will be discussed in detail to explore the influence of governing mechanisms on financial performance of banks in each country. Accordingly data collected from published annual reports of each banks from 2009 to 2013 for analysis in the CAMEL framework.

\section{Results and Discussions}

Table1 gives the analysis of performance of Bank of Ceylon (BoC) and Bank of Bhutan (BoB) under CAMEL framework. With regard to capital adequacy the first criteria determining the ability withstand unexpected losses (Sangmi and Nazir, 2010) although both banks are ahead of minimum requirements (10 percent in Sri Lanka) for capital adequacy, total assets to capital ratio of $\mathrm{BoB}$ in the decreasing trend while $\mathrm{BoC}$ in the increasing trend. However, according to scholars (e.g., Sangmi and Nazir, 2010) high capital adequacy also indicates conservativeness of fund utilization.

When considering asset quality in terms of non-performing loans to total loans is not available in BoB but it was in the increasing trend in $\mathrm{BoC}$ although the low ratio shows the prudent measures taken for recovery. The rising trend of this ratio in $\mathrm{BoC}$ shows the slacken trend in the recovery process.

It implies that non-performing loans are in the rise even though total loan amounts are also increasing. Managing efficiency which measured from ratio of operating profit to interest income shows that $\mathrm{BoB}$ is far ahead of BoC. It may that imply that operating profit of the $\mathrm{BoC}$ is higher than that of BoB.

Management quality is a qualitative measure but could be evaluated by certain quantitative measures. These measures would indicate the capability of the management to deploy its resources, aggressively to maximize the income, utilize the facilities in the bank productively and reduce costs (Purohit, et.al. 2003). When comparing management quality as a ratio of operating profit to interest income, the main source of bank income, $\mathrm{BoC}$ is far behind the BoB. This trend shows that high operating cost may resulted from comparable higher salaries and facilities offered to employees (Annual Reports, $\mathrm{BoC}$, various issues). In contrast, salaries and other facilities in $\mathrm{BoB}$ are not different from the overall salary structure of the country (BoB, Annual Reports) 
Upananda, W.A., Kumara, U.E.S. Wayamba Journal of Management 4 (2) 
Upananda, W.A., Kumara, U.E.S. Wayamba Journal of Management 4 (2) 
When the bank's performances are evaluated from as a ratio of return on asset (before taxes, return on investment, and return on equity, conventional measures of financial performance, $\mathrm{BoC}$ is, again, far behind BoB. Similarly, when compared with leading bank in Pakistan (Punjab National Bank, 2005 Annual Report) ROA: 1.117; RoE: 13.85) $\mathrm{BoC}$ is comparably higher but lower than BoB. This implies BoB is comparably progressive in comparison with state banks with a long history. Liquidity ratio is one measure this study draw attention although that is not available in BoB. However, Punjab National Bank (PNB) leading bank in Pakistan could be used to evaluate how
$\mathrm{BoC}$ is prudent in handling liquid asset. While all liquid ratios are below one (1) in PNB, BoC's comparable ratio are far higher implying handling excess liquid assets. This shows that BoC is not prudent in handling assets.

This argument is further proved when compared with another leading bank in Pakistan, Jammu And Kashmir Bank. The same ratios are below one while BoC's far higher than the perhaps, Asian average of handling liquid assets. As a result opportunities for investments on non-interest earning may have been ignored.

Table 2: Liquidity Ratios of Jammu And Kashmir Bank

\begin{tabular}{|l|l|l|l|l|l|l|l|l|}
\hline$\cdot$ & (5) Liquidity Ratios & $\mathbf{2 0 0 1}$ & $\mathbf{2 0 0 2}$ & $\mathbf{2 0 0 3}$ & $\mathbf{2 0 0 4}$ & $\mathbf{2 0 0 5}$ & Mean & $\begin{array}{l}\text { Standard } \\
\text { Deviation }\end{array}$ \\
\hline A & $\begin{array}{l}\text { Liquid Assets to total } \\
\text { Assets Ratio. }\end{array}$ & 0.161 & 0.133 & 0.090 & 0.137 & 0.129 & 0.130 & 0.025 \\
\hline B & $\begin{array}{l}\text { Govt. \& other } \\
\text { Securities to total } \\
\text { Assets. Investment } \\
\text { to total Assets) }\end{array}$ & 0.421 & 0.390 & 0.400 & 0.398 & 0.370 & 0.396 & 0.018 \\
\hline C & $\begin{array}{l}\text { Liquid Assets to } \\
\text { Deposits }\end{array}$ & 0.184 & 0.152 & 0.103 & 0.156 & 0.146 & 0.148 & 0.029 \\
\hline D to & $\begin{array}{l}\text { Investment } \\
\text { Deposits. }\end{array}$ & 0.480 & 0.444 & 0.458 & 0.452 & 0.419 & 0.450 & 0.022 \\
\hline
\end{tabular}

Source: Annual Reports of JKB (2001-005) as reported by Shangmi and Nazir (2010)

\section{Conclusion}

This study argues that governing mechanisms may have an influence over the financial performance of bank. Accordingly compared two banks; Bank of Ceylon under democratically elected government and Bank of Bhutan under monarchical form of government. Analyzing annual reports of both banks from 2009 to 2013 using CAMEL framework recommended by the Basel
Committee, this study concludes that state banks under monarchical governing mechanism in Bhutan have lesser intervention in managerial and financial decisions than state bank under democratic governing mechanism in Sri Lanka. As a result Bank of Ceylon of Sri Lanka may not be able utilized financial resource more prudently. 


\section{Reference}

Adam, C., Cavendish, W. and Mistry, P. (1992). Adjusting Privatization: Case Studies.

London: James Curry Ltd.

Bischofberger, A. and Rybach, M. (2003) 'Basel II implications for banks and banking markets', Credit Suisse Economic and Policy Consulting, Zurich, p. 11.

Bank of Ceylon, Annual Report (2009, 2010, 2011, 2012 and 2013), Bank of Ceylon, Colombo 1.

Bank of Bhutan, Annual Reports (2010, 2011, 2012, and 2013). Thimpu, Bhutan.

Caves, R.E. (1990). Lessons from privatization in Britain: State enterprise behavior, public

Choice and corporate governance. Journal of Economic Behavior and Organization, 13, 145-69.

Crama , Y., Leruth, L,. Renneboog, L and J.P. Urbain (2003). Corporate control concentration measurement and firm performance, In: J.A. Batten and T.A. Fetherston (Eds.) Social Responsibility: Corporate Governance Issues, Research in International Business and Finance, Volume 17, JAI Press, 123-49.

Eisenhardt, K.M. (1989). Building Theory from Case Study Research. Academy of Management Review, 14(4): 532-55.

Ghosh, S. (2010). How did state-owned banks respond to privatization? ,Evidence from the Indian experiment, http://mpra.ub.unimuenchen.de/24716/

Kelegama, S. (1997). 'Privatization: An overview of the Process and Issues', In Dilemmas of Development, Lakshaman, W. D.(Ed.), Sri Lanka Association of Economists, Colombo, Sri Lanka.

La porte, R., F. Lopez, D S., and A. Shleifer. (2002). Government ownership of banks. Journal of Finance, 57, 265-301.

Laffont, J. and. Tirole, J (1993). A theory of incentives in procurement and regulation. MIT Press, Cambridge, MA.

Modigliani,F. and Merton M. (1958) 'The cost of capital, corporate finance and the theory of investment', The American Economic Review, 48, No. 3, pp. 261-297.

Purohit, K. K. and Mazumdar, B. C. (2003). Post-Mortem of Financial Performance and Prediction of Future Earning Capability of a Bank: An Application of CAMEL Rating and Balanced Scorecard. Indian Journal of Accounting, 34 (1), 8-16.

Rodriguez, J. L. (2002) 'International banking regulation: Where's the market discipline in Basel II?', Cato Institute Policy Analysis No. 455, pp. 1-27.

Sangmi, M. (2002). financial performance Management in Commercial Banks: An Exploratory Study. The Business Review- Journal of the Faculty of Commerce and Management Studies- The University of 
Kashmir, Srinagar, 8(1 and 2), 3649.

Sangmi, M.and Nazir ,T. (2010). Analyzing Financial Performance of Commercial Banks in India: Application of CAMEL Model, Pakistan Journal of Commerce and Social Science, 4 (1), 40-55.

Santomero,A. M. and Allen, F. (1996). The Theory of Financial Intermediation, The Whorton Financial institutions Center, 9632.32

Sarker, J. and Sarker, S. and. Bhaumik, S,(1998). Does ownership always matter? Evidence from the Indian banking industry. Journal of Comparative Economics, 26, 26281.

Shleifer, A. and. Vishni, R (1994). Politicians and firms. Quarterly Journal of Economics, 109, 9951025.

Yin, R. K. (2003). Case Study Research: Design and Methods, Sage Publishers, London 